\title{
"Methodological support for estimating the level of internal communications efficiency at an enterprise"
}

\begin{tabular}{|c|c|}
\hline AUTHORS & Hanna Demchenko (D http://orcid.org/0000-0001-8550-8011 \\
\hline ARTICLE INFO & $\begin{array}{l}\text { Hanna Demchenko (2019). Methodological support for estimating the level of } \\
\text { internal communications efficiency at an enterprise. Development Management, } \\
17(2), 37-48 . \text { doi:10.21511/dm.17(2).2019.05 }\end{array}$ \\
\hline DOI & http://dx.doi.org/10.21511/dm.17(2).2019.05 \\
\hline RELEASED ON & Monday, 09 September 2019 \\
\hline RECEIVED ON & Saturday, 04 May 2019 \\
\hline \multirow[t]{2}{*}{ ACCEPTED ON } & Friday, 14 June 2019 \\
\hline & $(\mathrm{cc}) \mathrm{EY}$ \\
\hline LICENSE & $\begin{array}{l}\text { This work is licensed under a Creative Commons Attribution } 4.0 \text { International } \\
\text { License }\end{array}$ \\
\hline JOURNAL & "Development Management" \\
\hline ISSN PRINT & $2413-9610$ \\
\hline ISSN ONLINE & $2663-2365$ \\
\hline PUBLISHER & LLC "Consulting Publishing Company "Business Perspectives" \\
\hline FOUNDER & Simon Kuznets Kharkiv National University of Economics \\
\hline & 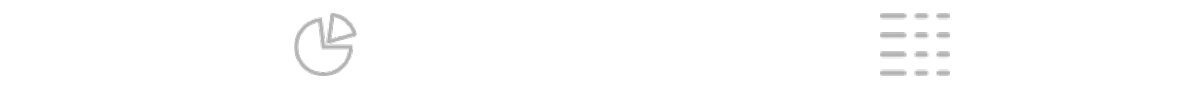 \\
\hline NUMBER OF REFERENCES & NUMBER OF FIGURES \\
\hline 25 & 3 \\
\hline
\end{tabular}

(C) The author(s) 2023. This publication is an open access article. 


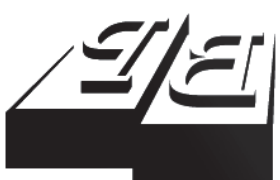

BUSINESS PERSPECTIVES

Publisher

LLC "CPC "Business Perspectives" Hryhorii Skovoroda lane, 10, Sumy, 40022, Ukraine www.businessperspectives.org

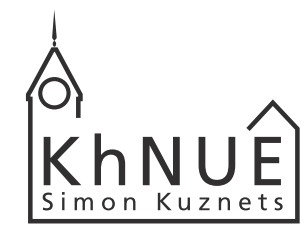

\section{S. KUZNETS KHNUE}

Founder

Simon Kuznets Kharkiv National University of Economics, Nauky avenue, 9-A, Kharkiv, 61166,

Ukraine

http://www.hneu.edu.ua/

Received on: $04^{\text {th }}$ of

May, 2019

Accepted on: $14^{\text {th }}$

of June, 2019

\section{() Hanna Demchenko, 2019}

Hanna Demchenko, Ph.D., Lecturer of the Department of Management, economy and logistics, Simon Kuznets Kharkov National University of Economics, Ukraine

\section{METHODOLOGICAL SUPPORT FOR ESTIMATING THE LEVEL OF INTERNAL COMMUNICATIONS EFFICIENCY AT AN ENTERPRISE}

\begin{abstract}
Systematic analysis of the level of communication efficiency at an enterprise ensures its increased performance. Thus, it helps to establish long-term partnership relations with contact audiences and to form consumer loyalty in the external environment. As for the internal environment of an enterprise, the analysis of communication processes can reveal the «unformalized» relations between management and subordinates, determine the degree of autonomy of the individual units, evaluate the effectiveness of the feedback between the components of the management structure. It thus helps to establish effective communication processes within the enterprise. Therefore, assessing the effectiveness of communication processes at an enterprise is of particular significance. In view of this, the purpose of the article is to develop a methodological support for estimating the level of internal communications efficiency at the enterprise. The system of indicators for the internal communications assessment has been proposed, which includes quantitative and qualitative indicators and makes it possible to comprehensively assess the state and the level of internal communications efficiency. In order to assess the level of internal communications effectiveness, the methodological approach is proposed, which is based on the use of expert methods, taking into account logical rules for constructing functions of each element attribute and the process of internal communications. This methodological approach may be used at the industrial enterprises in order to determine the level of internal communications efficiency at the operating departments or at the enterprise as a whole.
\end{abstract}

\section{Keywords}

JEL Classification

Г.В. Демченко (Україна) analysis, internal communication, level of efficiency, fuzzy logic, performance measures

$\mathrm{C} 02, \mathrm{C} 13, \mathrm{C} 15, \mathrm{D} 04$

\section{МЕТОДИЧНЕ ЗАБЕЗПЕЧЕННЯ ОЦІНКИ РІВНЯ ЕФЕКТИВНОСТІ ВНУТРІШНІХ КОМУНІКАЦІЙ НА ПІДПРИЕМСТВІ}

\begin{abstract}
Анотація
Систематичний аналіз рівня ефективності комунікацій на підприємстві забезпечує підвищення ефективності його функціонування, так, у зовнішньому оточенні він сприяє налагодженню довгострокових партнерських відносини із контактними аудиторіями та формуванню лояльності споживачів. Відповідно у внутрішньому середовищі - аналіз комунікаційних процесів дозволяє виявити неформалізовані відносини керівництва й підлеглих, визначити ступінь автономності діяльності окремих підрозділів, оцінити ефективність зворотного зв'язку між складовими структури управління, що сприяє встановленню ефективності комунікаційних процесів всередині підприємства. Тому вирішення питань оцінки ефективності комунікаційних процесів на підприємстві набуває особливої актуальності. У зв'язку з цим метою статті $є$ формування методичного підходу оцінки рівня ефективності внутрішніх комунікацій на підприємстві. Автором узагальнено систему показників оцінки внутрішніх комунікацій на підприємстві, яка містить кількісні та якісні показники та дає можливість комплексно оцінити стан та рівень ефективності внутрішніх комунікацій. Для виконання оцінки рівня ефективності внутрішніх комунікацій автором запропоновано методичний підхід, який базується на використанні експертних методів з урахуванням логічних правил щодо побудови функцій належності кожного елементу складової та процесу внутрішніх комунікацій. Зазначений методичний підхід
\end{abstract}


можливо застосовувати на промислових підприємствах з метою визначення рівня ефективності внутрішніх комунікацій окремих підрозділів, або підприємства в цілому.

Ключові слова Класифікація JEL аналіз, внутрішні комунікації, рівень ефективності, нечітка логіка, показники оцінки C02, C13, C15, D04

\section{ВСТУП}

В умовах динамічного функціонування та розвитку ринкової економіки комунікаційні процеси являють собою основу сучасної діяльності компаній оскільки забезпечують обмін інформацією у внутрішньому та зовнішньому середовищі підприємства. До теперішнього часу керівниками вітчизняних підприємств значення комунікацій для успішної діяльності є недооціненим.

Раціональний менеджмент комунікацій неможливий без аналізу його ефективності, оскільки це дозволяє: встановити рівень ефективності комунікаційних процесів на підприємстві та визначити резерви підвищення їх ефективності; виявити зворотній зв’язок між складовими структури управління; визначити неформалізовані відносини керівників та підлеглих; виконати оцінку ступеню автономності підрозділів підприємства. Рівень розвитку внутрішніх комунікацій також впливає на можливості підприємства успішно взаємодіяти із зовнішнім оточенням. Таким чином, головною умовою перетворення комунікацій в ефективний інструмент управління $є$ розробка методичного підходу до оцінки рівня ефективності внутрішніх комунікацій на підприємстві.

\section{1. ЛІТЕРАТУРНИЙ ОГЛЯА}

Теоретичні та методологічні проблеми комунікацій стали предметом досліджень багатьох вітчизняних та зарубіжних вчених, зокрема дослідження теоретичних аспектів здійснювали вчені: Адамс (2008), Беннет (1986), Файоль, Емерсон, Тейлор та Форд (2005), Ларьков (2008), Почепцова (2001), Панфілова (2001) та інші; вивченням особливостей комунікаційної взаємодії підприємства із зовнішнім оточенням розкрито в працях: Тимохіної (2013), Шпака (2011); особливості управління комунікаціями на підприємстві представлено в працях: Петкуна (2016), Міронової, Кухар та Ситнік (2015); проблематика між суб’єктної взаємодії та формування зворотного зв’язку як складової комунікації розкривається у працях Плотнікова та Волкової (2017); значну увагу аналізу ефективності комунікаційних зв’язків приділяли Сагер (2013), Суровцева (2009), Штефанич та Дячун (2014), Щебликіна, Щебликін та Харченко (2015), Чернишова (2003); класифікацію факторів, які впливають на ефективність комунікацій досліджено в роботах Війо (1974), Ларькова (2008), Молочника (2015). В результаті узагальнення досліджень вітчизняних та зарубіжних вчених визначено, що рівень ефективності внутрішніх комунікацій має значний вплив на успішність діяльності підприємства та вимагає постійного удосконалення методики аналізу з урахуванням сучасних умов господарювання. Зважаючи на наукові напрацювання 3 цієї проблематики слід зауважити, що в теперішній час відсутній підхід щодо оцінки рівня ефективності внутрішніх комунікацій на підприємстві в розрізі застосування якісних і кількісних показників. Це і обумовило вибір теми дослідження.

\section{2. МЕТА ДОСЛІДЖЕННЯ}

Формування методичного підходу оцінки рівня ефективності внутрішніх комунікацій на підприємстві.

\section{3. МЕТОДИ ДОСЛІДЖЕННЯ}

Теоретичною і методичною основою дослідження стали фундаментальні сучасні економічні теорії, наукові концепції, теоретичні розробки провідних вітчизняних і зарубіжних вчених щодо сутності, показників 
оцінки, методів аналізу ефективності внутрішніх комунікацій на підприємстві. Для досягнення поставленої мети використано систему загальнонаукових і спеціальних методів дослідження: теоретичне узагальнення, абстактно-логічний аналіз, системний аналіз та синтез, класифікації - для узагальнення системи показників оцінки внутрішніх комунікацій; нечіткої логіки - для розрахунку інтегрального показника рівня ефективності внутрішніх комунікацій; графічний метод - для унаочнення емпіричних даних і схематичного подання основних положень дослідження.

\section{4. РЕЗУЛЬТАТИ ДОСЛІДЖЕННЯ}

В результаті проведення соціологічних досліджень визначено, що 73\% американських та 80\% японських керівників вважають, що головною перепоною на шляху досягнення ефективної роботи $є$ недоліки в процесі комунікації на підприємстві [12, с. 31-34]. Ефективно працюючі керівники - це ті, які самі $\epsilon$ комунікативними та досягли успіхів в налагодженні комунікацій.

Згідно Чернишову (2003) комунікабельність розуміють, як здатність до комунікацій, налагодження контактів та досягнення взаєморозуміння. Сагер (2013) зазначає, що внутрішні комунікації собою канали зв'язку, які дозволяють здійснити взаємозв'язок між комунікативними групами на підприємстві. Вони можуть відноситися до конкретного працівника, або підрозділу чи передбачати інформацію для підприємства вцілому.

Суровцева (2009) вважає, що здійснення цілеспрямованого впливу на працівників з метою прийняття, обробки, накопичення та передачі інформації на певні рівні управління (точки відповідальності), являють собою процес управління внутрішніми комунікаціями. Ефективність внутрішніх комунікації це досягнення їх основних цілей, а саме: інформування співробітників, зміна їх поведінки, формування групової думки.

Складність та багатогранність визначення рівня ефективності внутрішніх комунікацій вимагає додаткових досліджень у визначенні його основних показників оцінки, методів аналізу та оцінки. Дійсним дослідженням пропонується методичний підхід до оцінки рівня ефективності внутрішніх комунікацій, який здійснюється у три етапи (Рисунок 1).

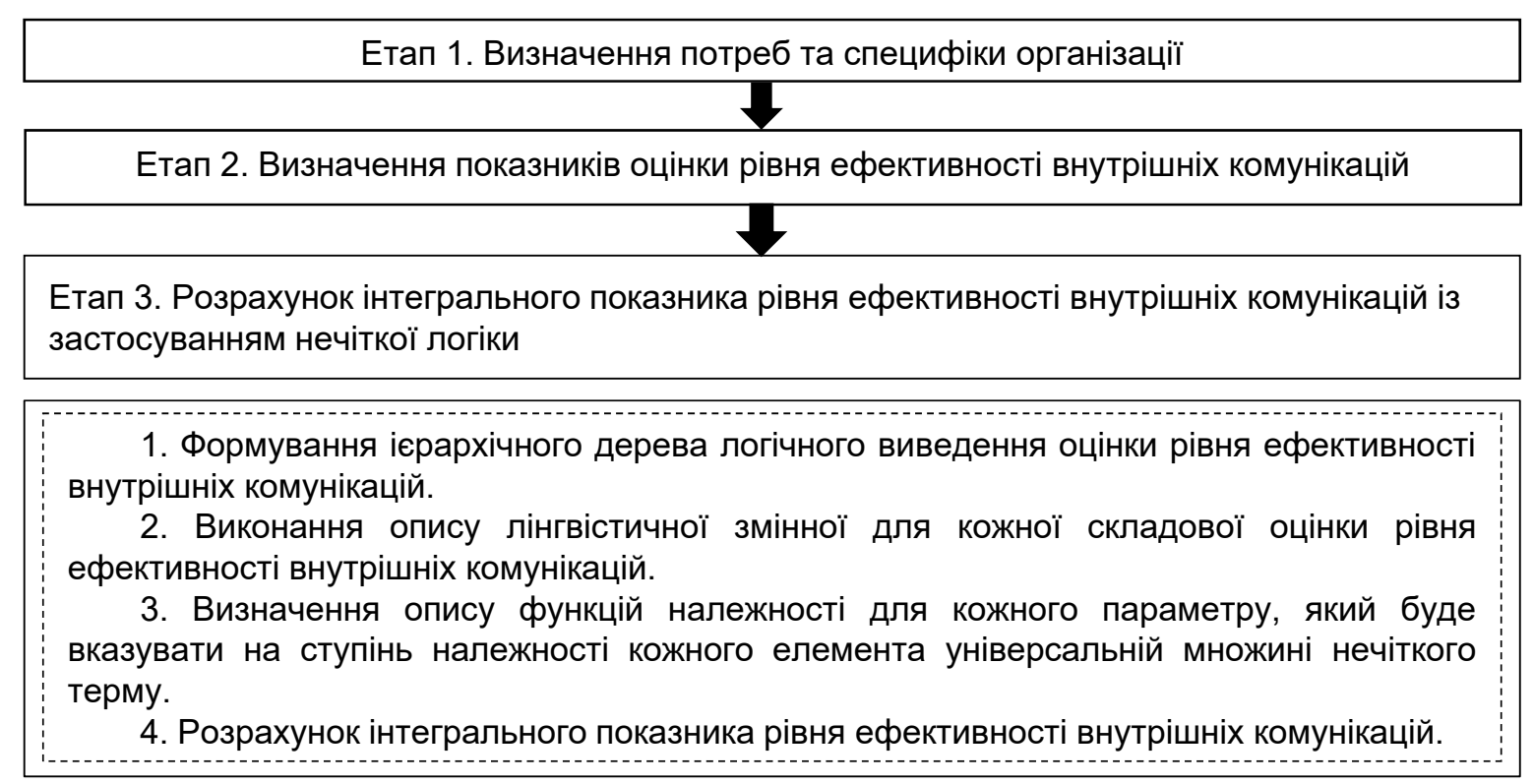

Джерело: Розроблено автором

Рисунок 1. Методичний підхід до оцінки рівня ефективності внутрішніх комунікацій 
На першому етапі визначають цілі підприємства, особливості внутрішнього і зовнішнього оточення, виявляють комунікаційні проблеми, що заважають розвитку підприємства.

Другий етап пов язаний з вибором показників оцінки внутрішніх комунікацій. Питання методології формування показників оцінки ефективності комунікаційних процесів на підприємстві, системно висвітлюються в наукових працях Сагера (2013), Штефанича (2014), Чернишова (2003), Суровцевої (2009). Розглянувши існуючі розробки та положення, слід зазначити, що важливі аспекти оцінки поточного стану та рівня ефективності внутрішніх комунікацій в сучасних умовах потребують систематичної уваги та розвитку.

Виділяють два радикально різних підходи до вибору показників оцінювання: суб’єкивний та об’єктивний. До суб’єктивних способів оцінювання внутрішніх комунікацій можна віднести методи із застосуванням експертної оцінки, в результаті чого буде отримано якісні показники оцінки [15]. Під час проведення експертного оцінювання існує загроза недостатньої його компетентності, об'єктивності, впливу на нього емоційних та психологічних факторів, наявність антагонізму між деякими експертами $[10$, c. 5]. Прихильники об’єктивного підходу акцентують увагу на лише кількісних показниках оцінки, які дозволяють отримати виключно об’єктивну картину рівня ефективності комунікацій, а саме: фактичні дані із звітності підприємства [12, с. 25].

На основі аналізу праць Ларькова (2008), Молочника (2015), Панфілової (2001), Петкуна (2016), Сагера (2013), Суровцевої та Рубіна (2009), Штефанича та Дячун (2014), Щебликіна та Щебликіної (2015) в таблиці 1 запропоновано систему показники оцінки, які характеризують складові і процеси внутрішніх комунікацій підприємства. Система надає можливість комплексно оцінити ефективність внутрішніх комунікацій підприємства.

Таблиця 1. Склад показників оцінки рівня ефективності внутрішніх комунікацій підприємства

Джерело: Складено автором.

\begin{tabular}{|c|c|}
\hline $\begin{array}{l}\text { Складова та } \\
\text { процес }\end{array}$ & Параметри оцінки \\
\hline \multirow{4}{*}{$\begin{array}{l}\text { Організаційна } \\
\text { структура (ОС) }\end{array}$} & $\begin{array}{l}\text { • Рівень гнучкості організаційної структури в процесі прийняття рішень та налагодженню } \\
\text { взаємозв'язків (a1) }\end{array}$ \\
\hline & - $\quad$ Рівень збалансованості та координації структури (а2) \\
\hline & • Рівень оперативності передачі інформації (а3) \\
\hline & • $\quad$ Рівень досягнення поставлених завдань (a4) \\
\hline \multirow{11}{*}{ Персонал (П) } & - Загальний стаж роботи співробітника на підприємстві (a6) \\
\hline & - $\quad$ Показник самонавчання співробітника (a7) \\
\hline & - $\quad$ Рівень заохочення співробітника до навчання (а8) \\
\hline & - $\quad$ Рівень креативності мислення співробітника (а9) \\
\hline & - $\quad$ Рівень мотивації співробітника (а10) \\
\hline & • Ступінь обміну інформацією між персоналом підприємства (а12) \\
\hline & • $\quad$ Ступінь використання окремих показників баз даних, форм документів підприємства (а13) \\
\hline & $\begin{array}{l}\text { - Рівень забезпеченості співробітника якісною інформацією, яка характеризує «зовнішнє оточення» } \\
\text { підприємства (a14) }\end{array}$ \\
\hline & • $\quad$ Ступінь зворотнього зв'язку в колективі (a15) \\
\hline & - $\quad$ Рівень комунікативних розривів в колективі (a16) \\
\hline & Ступінь тривалості комунікаційних зв'язків (а17) \\
\hline \multirow{2}{*}{$\begin{array}{l}\text { Процес формування } \\
\text { ціннісної орієнтації } \\
\text { (ПФЦО) }\end{array}$} & $\begin{array}{l}\text { Наявність заходів, які сприяють розвитку у співробітників цінностей взаємодії (підтримка, } \\
\text { командність, довіра, надійність, стабільність, справедливість, солідарність, відповідальність) (а18) }\end{array}$ \\
\hline & $\begin{array}{l}\text { - Наявність заходів, які стимулюють у співробітників розвиток цінностей-засобів, що сприяють } \\
\text { формуванню середовища сприятливого для розвитку внутрішніх комунікацій (самореалізація, } \\
\text { творчість, дисциплінованість, інноваційність, організованість) (а19) }\end{array}$ \\
\hline
\end{tabular}


Таблиця 1 (продовження). Склад показників оцінки рівня ефективності внутрішніх комунікацій підприємства

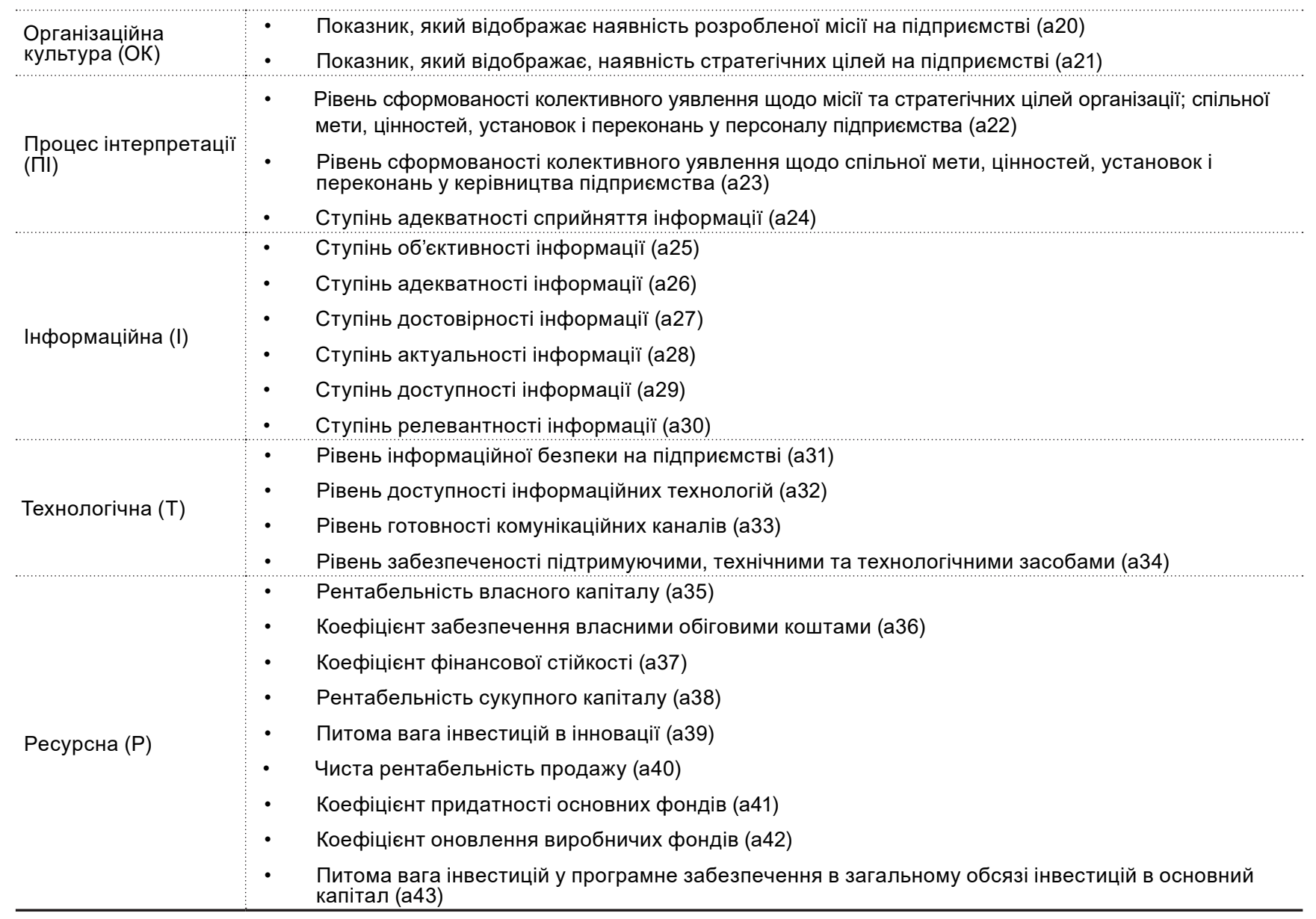

Запропонована в Таблиці 1 система складається з кількісних і якісних показників, що надає можливість комплексно оцінити рівень ефективності внутрішніх комунікацій та уникнути ризиків, пов’язаних 3 застосуванням експертних оцінок.

Розглянемо докладніше представлені в Таблиці 1 складові системи показників.

Організаційна структура. Її показники характеризують гнучкість та оперативність системи внутрішніх комунікацій по відношенню до постійних змін факторів зовнішнього та внутрішнього середовища. Залежно від того, яка саме організаційна структура функціонує на підприємстві та як її відображено в інформаційному просторі, буде залежати ієрархічність передачі інформації, рівні оперативності, рівень надійності, збалансованості та координації.

Персонал. Від знань, досвіду, кваліфікації, навичок, персоналу залежить ефективність комунікацій на підприємстві. Під час оцінки внутрішніх кадрів необхідно враховувати склад кадрів керівників і фахівців за кваліфікацією, професійною підготовкою, стажем роботи, а також - рівень організації цільової навчання, зростання кваліфікації і перепідготовки кадрів, стабільність кадрів і їх просування, завантаженість окремих категорій працівників.

Процес формування ціннісної орієнтації. Визначає ступінь ефективності заходів, що сприяють розвитку у співробітників цінностей взаємодії та забезпечують сприятливе для комунікацій середовищем. 
Організаційна культура. Вивчення організаційної культури передбачає оцінку базових припущень, в основі яких лежать філософські аспекти, що впливають на сприйняття навколишнього світу членами організації. Формування спільних цінностей, що об'єднують зусилля всього персоналу компанії для досягнення поставлених цілей.

Процес інтерпретації визначає рівень достовірності інтерпретації інформації реципієнтом, швидкість та вчасність ї̈ доведення - координаційно-просторові критерії. Психологічний аспект комунікацій на рівні процесів має важливе значення, і те, як саме працівник інтерпретує доведену у його розпорядження інформацію.

Інформаційна складова. Її показники характеризують рівень якості інформації та ступінь їїрелевантності, оскільки в першу чергу від цього залежить раціональність рішень, що приймає менеджер на підприємстві.

Показники технологічної складової характеризують рівень готовності, доступності та безпеки інформації на підприємстві. Вчені Міронова, Кухар та Ситнік (2015) зазначають, що максимально ефективний результат під час поширення інформації з певного питання можна досягти шляхом користування водночас кількома каналами, але потрібно враховувати ймовірність того, що при декодуванні в таке повідомлення може потрапити семантична помилка.

Ресурси. Передбачає оцінку наявності необхідних ресурсів, що забезпечують функціонування комунікаційного простору. Найважливіша складова, адже саме від наявності достатньої кількості ресурсів на підприємстві залежатиме, який саме комунікаційний простір, з використанням яких технічних засобів обере для себе підприємство.

Третій етап методичного підходу пов’язано з вибором та застосуванням методу економіко-математичного моделювання для визначення рівня ефективності внутрішніх комунікацій на підприємстві. Специфіка дослідження оцінки структури та елементів внутрішніх комунікацій полягає у складності вибору методу, який дозволяє проаналізувати якісні та кількісні показники одночасно.

Аналіз праць вчених Леоненкова (2003), Ротштейна (1999), Штовби (2007) підтверджує, що нечітка логіка являє собою найперспективніший напрям наукових досліджень в галузі аналізу та прогнозування економічних явищ і процесів, що мають обмежену кількість статистичних даних та мають складну функціональну залежність. Апарати нечітких множин та нечіткої логіки призначені для роботи із числовими і нечисловими даними та налаштування моделі відповідно до реальних даних.

Таким чином на третьому етапі запропоновано формування та розрахунок єдиного інтегрального показника, що у кількісному вимірі визначатиме рівень ефективності внутрішніх комунікацій підприємства, його складових та процесів, які мають кількісні та якісні показники виміру.

Основні поняття нечітких множин є стандартними і наведені у працях Ротштейна (1999) та Штовби (2007). Запропонований методичний підхід визначення рівня ефективності внутрішніх комунікацій включає наступні етапи.

Етап 1. Побудова ієрархічного дерева логічного виведення оцінки рівня ефективності внутрішніх комунікацій на підприємстві.

Інтегральна оцінка рівня ефективності внутрішніх комунікацій на підприємстві має ієрархічний зв〉язок складових та процесів з параметрами оцінки, що доцільно представити у вигляді графу (дерева) нечіткої багаторівневої системи, який визначатиме структуру моделі нечіткого дерева. У відповідності 3 визначеними складовими та процесами оцінки рівня ефективності внутрішніх комунікацій підприємства $\left(\mathrm{PEBK}_{\text {підр }}\right)$, які узагальнено в Таблиці 1 , здійснено побудову ієрархічного дерева логічного виведення (Рисунок 2). 


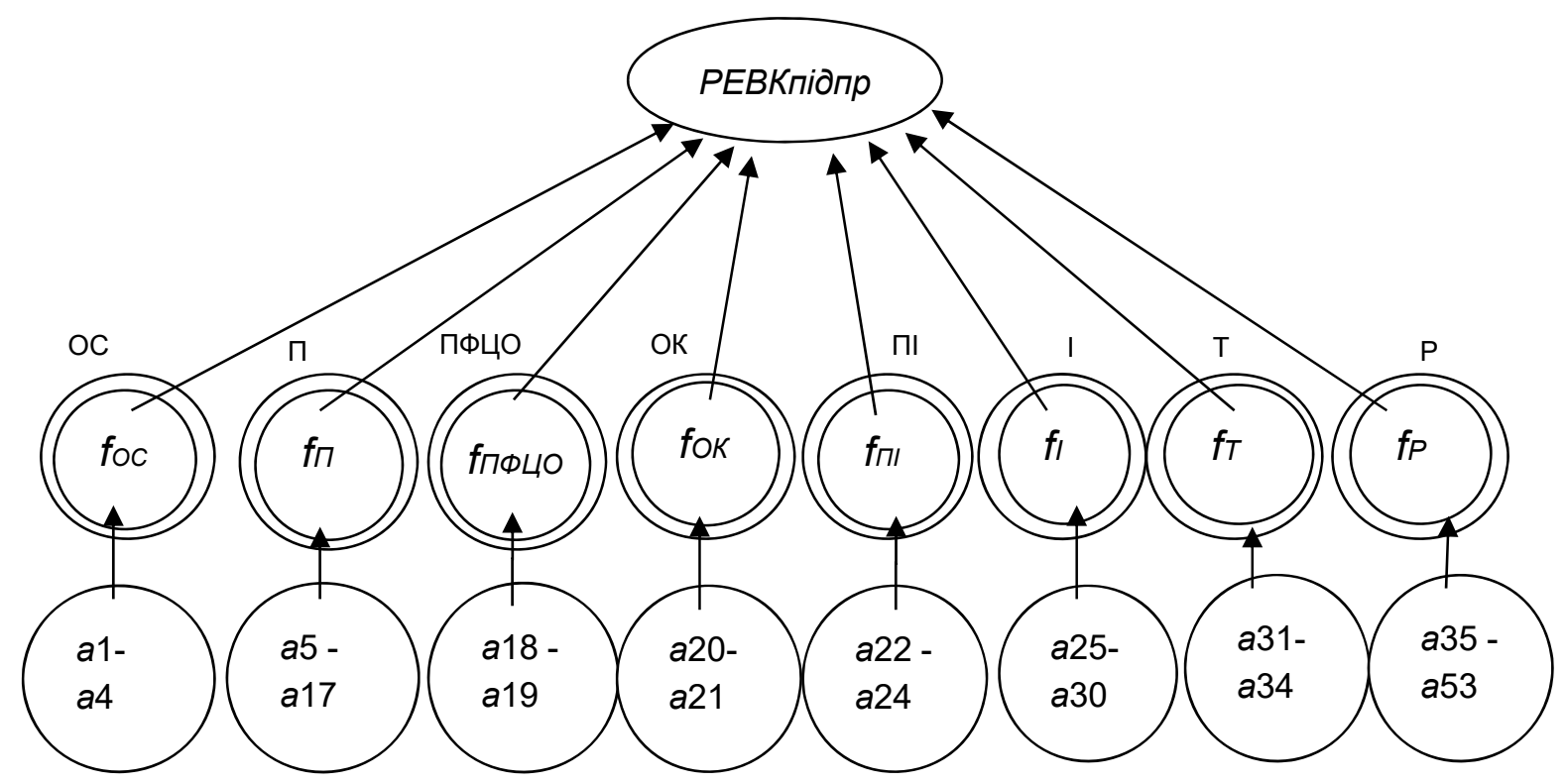

Рисунок 2. Ієрархічне дерево логічного виведення оцінки рівня ефективності внутрішніх комунікацій на підприємстві

Елементи дерева інтерпретуються наступним чином:

- $\quad$ корінь дерева - рівень ефективності внутрішніх комунікацій підприємства (інтегральний показник);

- термальні вершини - частинні оцінки $\left(\mathrm{a}_{1} \ldots \mathrm{a}_{n}\right)$ рівня ефективності внутрішніх комунікацій, визначені в ході теоретичного дослідження;

- $\quad$ нетермальні вершини (подвійні окружності) - згортки частинних оцінок, що відображають складові і процеси внутрішніх комунікацій.

Етап 2. Виконання опису лінгвістичної змінної для кожної складової оцінки рівня ефективності внутрішніх комунікацій.

Під часпобудови моделей систем іпроцесів із застосуванням апарату нечіткої логіки та нечіткомножинного підходу, вхідні змінні представляються як лінгвістичні. Для опису лінгвістичних змінних слід задати ïx ім'я $(x)$, лінгвістичні терм-множини $(T)$, кожний елемент яких (терм) $є$ нечіткою множиною на універсальній множині (U) [5, с. 93].

В Таблиці 2 наведено лінгвістичні змінні нечіткої моделі оцінки для складової «Організаційна структура». 
Таблиця 2. Значення лінгвістичних змінних нечіткої моделі оцінки ефективності внутрішніх комунікацій на підприємстві на прикладі складової «Організаційна структура»

Джерело: Складено автором.

\begin{tabular}{|c|c|c|c|}
\hline Параметр & $\begin{array}{c}\text { Назва лінгвістичної змінної } \\
(x)\end{array}$ & Універсальна множина (U) & Лінгвістичні терми (Т) \\
\hline \multirow{6}{*}{ a1 } & \multirow{6}{*}{$\begin{array}{l}\text { Рівень гнучкості організаційної } \\
\text { структури в процесі прийняття } \\
\text { рішень та налагодженню } \\
\text { взаємозв'язків }\end{array}$} & $(0-100] \%$ & \multirow{6}{*}{$\begin{array}{l}\text { Low (низький) } \\
\text { Medium (нижче за середній) } \\
\text { Medium (середній) } \\
\text { High Medium (вище за середній) } \\
\text { High (високий) }\end{array}$} \\
\hline & & $(0-20] \%-$ низький & \\
\hline & & $(20-40] \%$ - нижче за середній & \\
\hline & & $(40-60] \%$ - середній & \\
\hline & & $(60-80] \%$ - вище за середній & \\
\hline & & $(80-100] \%-$ високий & \\
\hline \multirow{6}{*}{ a2 } & \multirow{6}{*}{$\begin{array}{l}\text { Рівень збалансованості та } \\
\text { координації системи }\end{array}$} & $(0-100] \%$ & \multirow{6}{*}{$\begin{array}{l}\text { Low (низький) } \\
\text { Medium (нижче за середній) } \\
\text { Medium (середній) } \\
\text { High Medium (вище за середній) } \\
\text { High (високий) }\end{array}$} \\
\hline & & $(0-20] \%-$ низький & \\
\hline & & $(20-40] \%$ - нижче за середній & \\
\hline & & $(40-60] \%$ - середній & \\
\hline & & $(60-80] \%$ - вище за середній & \\
\hline & & $(80-100] \%$ - високий & \\
\hline \multirow{6}{*}{ a3 } & \multirow{6}{*}{ Рівень оперативності інформації } & $0-100 \%$ & \multirow{6}{*}{$\begin{array}{l}\text { Low (низький) } \\
\text { Medium (нижче за середній) } \\
\text { Medium (середній) } \\
\text { High Medium (вище за середній) } \\
\text { High (високий) }\end{array}$} \\
\hline & & $(0-20] \%-$ низький & \\
\hline & & $(20-40] \%$ - нижче за середній & \\
\hline & & $(40-60] \%$ - середній & \\
\hline & & $(60-80] \%$ - вище за середній & \\
\hline & & $(80-100] \%$ - високий & \\
\hline \multirow{6}{*}{ a4 } & \multirow{6}{*}{$\begin{array}{l}\text { Рівень досягнення поставлених } \\
\text { завдань }\end{array}$} & $0-100 \%$ & \multirow{6}{*}{$\begin{array}{l}\text { Low (низький) } \\
\text { Medium (нижче за середній) } \\
\text { Medium (середній) } \\
\text { High Medium (вище за середній) } \\
\text { High (високий) }\end{array}$} \\
\hline & & $(0-20] \%-$ низький & \\
\hline & & $(20-40] \%$ - нижче за середній & \\
\hline & & $(40-60] \%$ - середній & \\
\hline & & $(60-80] \%$ - вище за середній & \\
\hline & & $(80-100] \%-$ високий & \\
\hline
\end{tabular}

Дані Таблиці 2 розроблено та змістовно обгрунтовано на основі законів, вимог та стандартної пента шкали, що визначена на основі стандартного п’ятирівневого нечіткого 01 класифікатора.

Вихідна змінна - рівень ефективності внутрішніх комунікацій набуватиме значення: низький (Low), нижче за середній (Low Medium), середній (Medium), вище за середній (High Medium), високий (High) на універсальній множині (0-100 балів). Інтервал зміни кожного параметра був заданий від двох до п'яти лінгвістичними термами, які визначені на основі обробки результатів експертного опитування. Чим вище рівень ефективності внутрішніх комунікацій на підприємстві, тим він ближче до 100.

Етап 3. Визначення опису функцій належності для кожного параметру системи оцінки внутрішніх комунікацій, що буде вказувати на ступінь належності кожного елемента універсальній множині нечіткого терму.

Функція належності визначає ступінь належності нечіткій множині довільного елемента універсальної множини. Із застосуванням процедури дефаззифікації, яка в теорії нечітких множин $є$ аналогом знаходження характеристик становища (математичного сподівання, моди, медіани) випадкових величин в теорії ймовірності, відбувається перетворення нечіткої множини в чітке число. Нечіткий логічний вивід - апроксимація залежності «входи-вихід» при використанні апарату нечіткої логіки здійснюється на підставі правил типу <Якщо-то> та операцій над нечіткими множинами [5, с. 93].

Згідно з Леоненковим (2003) типова структура системи нечіткого виведення містить такі модулі:

- фазифікатор, який перетворює фіксований вектор факторів, що впливають $(X)$ у вектор нечітких множин $X$, необхідних для нечіткого виведення; 
- нечітка база знань, яка містить інформацію про залежність $Y=f(X)$ у вигляді лінгвістичних правил: $<$ Якщо-то>;

- функції приналежності, які використовуються для представлення лінгвістичних термів у вигляді нечітких множин;

- машина нечіткого логічного виведення, яка на основі правил бази знань визначає значення вихідної змінної у вигляді нечіткої множини $(Y)$, що відповідає нечітким значенням вхідних змінних $(X)$;

- дефазифікатор, який перетворює вихідну нечітку множину $(X)$ в чітке число $(Y)[6$, c. 23].

Для проектування системи використано засоби Fuzzy Logic Toolbox системи Matlab, яка містить набір GUI-модулей, що забезпечує проведення етапу структурної ідентифікації в діалоговому режимі.

На Рисунку 2 представлено приклад графіків функцій належності нечітких термів вихідної лінгвістичної змінної «Організаційна структура».

Нечітке виведення Мамдані буде виконуватися на базі знань, яку представлено в Таблиці А.1 (додаток А), всі значення вхідних та вихідних змінних бази задані нечіткими множинами. Аналогічно формуються нечіткі бази знань для оцінки всіх інших складових і процесів.

Далі виводяться нечіткі логічні рівняння, які будуть використовуватися для обчислення значення вихідного параметра при фіксованих значеннях вхідних параметрів. Рівняння отримують з нечітких логічних висловлювань, замінюючи терми лінгвістичних змінних відповідними функціями належності, а операції «і» та «або» - операціями знаходження мінімуму «і» та максимуму «або» відповідно [4, с. 84].

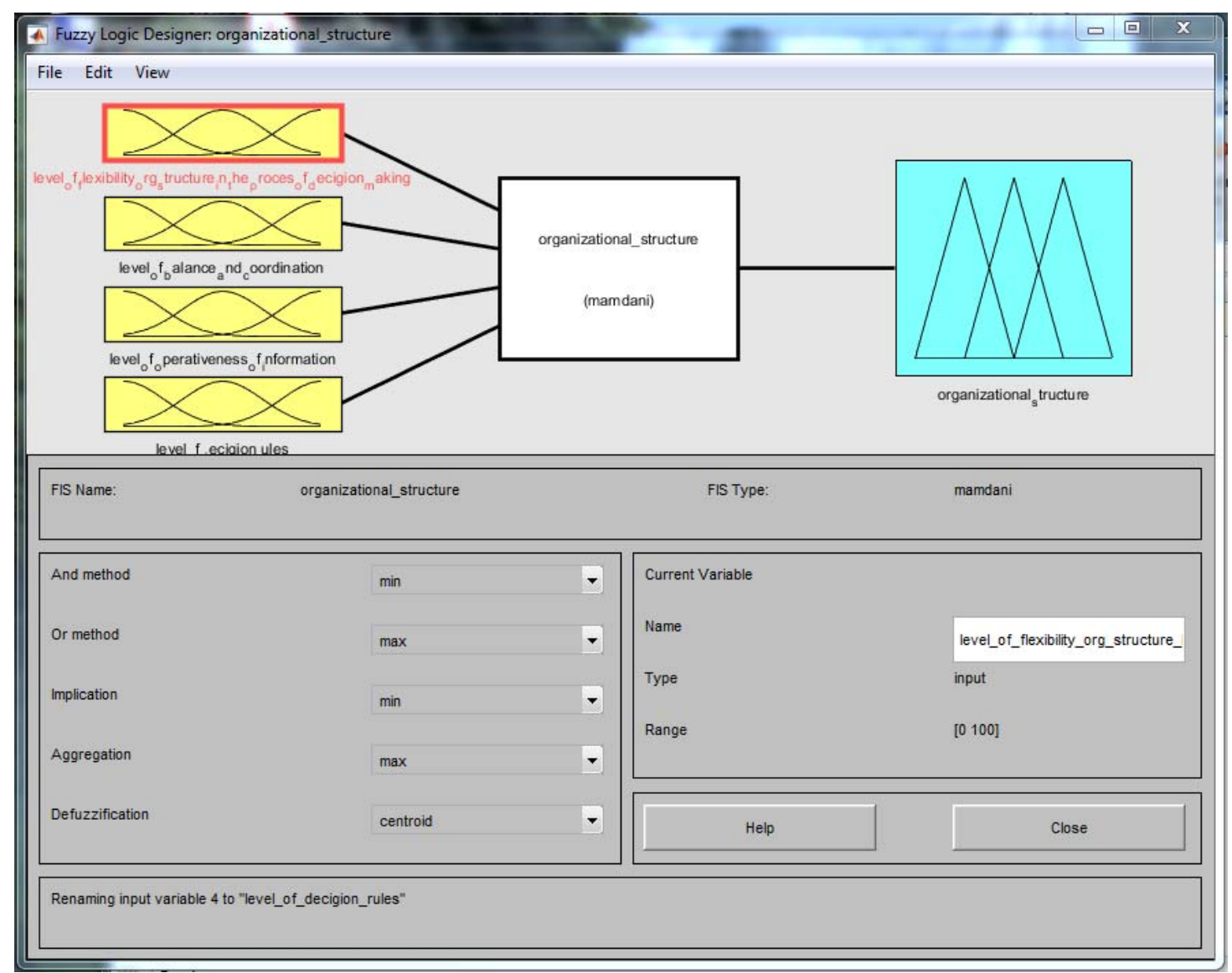


Етап 4. Розрахунок інтегрального показника рівня ефективності внутрішніх комунікацій підприємства.

Перевірка створеної моделі на адекватність та розрахунок рівня ефективності внутрішніх комунікацій здійснюється за допомогою вводу даних фактичних даних з підприємства.

\section{ВИСНОВКИ}

В результаті дослідження обгрунтовано методичний підхід до оцінки ефективності внутрішніх комунікацій на підприємстві, особливостями якого є застосування апарату нечіткої логіки для аналізу систематизованих якісних та кількісних показників складових та процесів внутрішніх комунікацій на підприємстві, а саме: організаційна структура, персонал, процес формування ціннісної орієнтації, організаційна культура, процес інтерпретації, інформаційна, технологічна та ресурсна, що дозволяють визначити стан і рівень ефективності, як кожної складової, або процесу, так і в цілому внутрішніх комунікацій на підприємстві, що підвищує достовірність та об’єктивність прийняття управлінських рішень.

\section{СПИСОК ЛІТЕРАТУРИ}

1. Adams, В. (2008). Эффективное управление персоналом [Effektivnoe upravlenie personalom] (352р.). Moscow: AST. Astrel.

2. Bennet, M. A. (1986). Toward ethnorelativism: a developmental model of intercultural sensitivity. In Paige, R. M. (Ed). Cross-cultural orientation: new conceptualisation and application. Lanham: University Press of America.

3. Chernyishev, R. V. (2003). Проблемы повышения эффективности коммуникаций в процессе управления предприятием [Problemyi povyisheniya effektivnosti kommunikatsiy v protsesse upravleniya predpriyatiem]. Upravlenie sotsialnyimi protsessami $v$ transformatsionnoy ekonomike, 2, 25-32.

4. Demchenko, G. V. (2017). Застосування апарату нечіткої логіки у формуванні комплексної оцінки організаційного забезпечення активізації інноваційної діяльності промислового підприємства [Zastosuvannia aparatu nechitkoi lohiky u formuvanni kompleksnoi otsinky orhanizatsiinoho zabezpechennia aktyvizatsii innovatsiinoi diialnosti promyslovoho pidpryiemstva]. Naukovyi visnyk Mizhnarodnoho humanitarnoho universytetu, 18, 79-85. Retrived from http://www.vestnik-econom.mgu.od.ua/journal/2017/26-1-2017/18.pdf

5. Fayol, A., Emerson, G., Teylor, F., \& Ford, G. (2005). Управление - это наука и искусство [Upravlenie - eto nauka i iskusstvo] (560 p.). Moscow: Akademicheskiy Proekt.

6. Larkov, N. S. (2008). Документоведение [Dokumentovedenie] (432 p.). Moscow: AST. Vostok-Zapad.

7. Leonenkov, A. V. (2003). Нечеткое моделирование в среде MATLAB и fuzzyTECH [Nechetkoe modelirovanie $v$ srede MATLAB i fuzzyTECH] (736 p.). Sankt-Peterburh: BKhV-Peterburh.

8. Mironova, Yu. V., Kukhar, A. V., \& Sytnik, O. D. (2015). Особливості управління маркетинговою інформацією виробничого підприємства [Osoblyvosti upravlinnia marketynhovoiu informatsiieiu vyrobnychoho pidpryiemstva]. Ekonomichnyi prostir, 95, 220-230. Retrieved from http://nbuv.gov.ua/UJRN/ecpros_2015_95_24

9. Molochnyk, Yu. B. (2015). Використання системи збалансованих показників для оцінювання вмінь працівників комунікаційної системи підприємств [Vykorystannia systemy zbalansovanykh pokaznykiv dlia otsiniuvannia vmin pratsivnykiv komunikatsiinoi systemy pidpryiemstv]. Visnyk Natsionalnoho tekhnichnoho universytetu «KhPI». Seriia: Stratehichne upravlinnia, upravlinnia portfeliamy, prohramamy ta proektamy, 2, 166-172. Rretrieved from http://nbuv.gov.ua/UJRN/vntux_ctr_2015_2_32

10. Novosad, V. P., \& Seliverstov, R. G. (2008). Методологія експертного оцінювання [Metodologija ekspertnogo осіпјиvanпja] (48 p.). Kуiv: NADU.

11. Panfylova, A. Р. (2001). Деловая коммуникация в профессиональной деятельности [Delovaia kommunykatsyia v professyonalnoi deiatelnosty] (163 p.). Sankt-Peterburg: Soyuz.

12. Petkun, S. М. (2016). Комунікація у процесі управління підприємством [Komunikatsiia u protsesi upravlinnia pidpryiemstvom]. Ekonomika. Menedzhment. Biznes, 3, 24-31. Retrieved from http://journals.dut.edu.ua/index.php/emb/article/download/752/697

13. Plotnykov, M. V., \& Volkova, E. V. (2017). Внутрикорпоративные коммуникации как объект исследования современной социологии управления [Vnutrikorporativnyie kommunikatsii kak obekt issledovaniya sovremennoy sotsiologii upravleniya]. Sotsialno-ekonomicheskie preobrazovaniya i problemyi, 7, 67-79. Retrived from https://publications.hse.ru/mirror/pubs/share/direct/214711534

14. Pocheptsov, H. Н. (2001). Теория коммуникаиий [Teoriya kommunikatsiy] (656 p.). Moscow: Refl-buk.

15. Rotshtein, A. Р. (1999). Интеллектуальные технологи идентификации: нечеткая логика, генетические алгоритмы, нейронные сетu [Intellektualnyie tehnologi identifikatsii: nechetkaya logika, geneticheskie algoritmyi, neyronnyie seti] (295 p.). Vynnytsa: UniversumVinnytsia.

16. Saher, L. Yu. (2013). Формування методичного апарату оцінювання ефективності комунікаційної діяльності промислового підприємства [Formuvannia metodychnoho aparatu otsiniuvannia efektyvnosti komunikatsiinoi diialnosti promyslovoho pidpryiemstva]. Efektyvna ekonomika, 1. Retrived from http://nbuv.gov.ua/UJRN/efek_2013_1_39 
17. Shcheblykina, I. O., Shcheblykina, Z. V., \& Kharchenko, D. U. (2015). Управління комунікаційними процесами сучасних підприємств [Upravlinnia komunikatsiinymy protsesamy suchasnykh pidpryiemstv]. Zbirnyk naukovykh prats Tavriiskoho derzhavnoho ahrotekhnolohichnoho universytetu (ekonomichni nauky), 1(29), 124-127. Retrieved from http://journal.tsatu.edu.ua/index.php/econ/article/view/231

18. Shpak, N. O. (2011). Основи комунікаиійного менеджменту промислових підприємств [Osnovy komunikatsiinoho menedzhmеntu promyslovykh pidpryiemstv] (328 p.). Lviv: Vydavnytstvo Lvivskoi politekhniky.

19. Shtefanych, D., \& Diachun, O. (2014). Оцінка ефективності комунікаційної політики підприємства [Otsinka efektyvnosti komunikatsiinoi polityky pidpryiemstva]. Visnyk Ternopilskoho natsionalnoho ekonomichnoho universytetu, 1, 111-121. Retrieved from http://nbuv. gov.ua/UJRN/Vtneu_2014_1_12

20. Shtovba, S. D. (2007). Проектирование нечетких систем средствами MATLAB [Proektirovanie nechetkih sistem sredstvami MATLAB] (288 p.). Moscow: Goryachaya liniya-Telekom.

21. Surovtseva, E. K., \& Rubin, G. Үa. (2009). Оценка эффективности деятельности по управлению организационными коммуникациями [Otsenka effektivnosti deyatelnosti po upravleniyu organizatsionnyimi kommunikatsiyami]. Organizator proizvodstva, 4, 47-49.

22. Tymokhina, Ya. О. (2013). Інтегровані маркетингові комунікації: періодизація розвитку та визначення понять [Intehrovani marketynhovi komunikatsii: periodyzatsiia rozvytku ta vyznachennia poniat]. Stalyi rozvytok ekonomiky, 4, 324-328. Retrieved from http:// nbuv.gov.ua/UJRN/sre_2013_4_70

23. Vengrina, O. S., \& Starkova, O. V. (2017). Інформаційна система вибору функціонального призначення продукту проекту редевелопменту з використанням апарату нечіткої логіки [Informatsiina systema vyboru funktsionalnoho pryznachennia produktu proektu redevelopmentu z vykorystanniam aparatu nechitkoi lohiky]. Upravlinnja rozvytkom skladnyh system, 30, 92-100. Retrived from http://urss.knuba.edu.ua/files/zbirnyk-30/13.pdf

24. Wiio, O. (1974). Auditing communication in organizations: a standart survey, LTT communication audits. In Helsila, M. (Ed.). Finnish journal of business economics, 4, 305-315.

25. Zadeh, L. A. (1978). Fuzzy sets as a basis for a theory of possibility. Fuzzy sets and systems, 1(1), 9-34. https://doi.org/10.1016/S01650114(99)80004-9

\section{ДОДАТОК А}

Таблиця А.1. Матриця знань для оцінки складової «Організаційна структура»

Джерело: Складено автором

\begin{tabular}{|c|c|c|c|c|c|}
\hline \multicolumn{4}{|c|}{ Значення лінгвістичних термів на вході } & \multirow{2}{*}{$\begin{array}{c}\text { 3начення на виході } \\
\text { «організаційна } \\
\text { структура» }\end{array}$} & \multirow{2}{*}{$\begin{array}{c}\text { Вага } \\
\text { правила }\end{array}$} \\
\hline a1 & a2 & a3 & a4 & & \\
\hline Low & Low & Low & Low & \multirow{5}{*}{ Low } & 1 \\
\hline Low & Low & Low & $\begin{array}{l}\text { Low } \\
\text { Medium }\end{array}$ & & 1 \\
\hline Low & Low & $\begin{array}{l}\text { Low } \\
\text { Medium }\end{array}$ & Low & & 1 \\
\hline Low & $\begin{array}{l}\text { Low } \\
\text { Medium }\end{array}$ & Low & Low & & 1 \\
\hline $\begin{array}{l}\text { Low } \\
\text { Medium }\end{array}$ & Low & Low & Low & & 1 \\
\hline $\begin{array}{l}\text { Low } \\
\text { Medium }\end{array}$ & $\begin{array}{l}\text { Low } \\
\text { Medium }\end{array}$ & Low & Low & \multirow{6}{*}{$\begin{array}{l}\text { Low } \\
\text { Medium }\end{array}$} & 1 \\
\hline $\begin{array}{l}\text { Low } \\
\text { Medium }\end{array}$ & $\begin{array}{l}\text { Low } \\
\text { Medium }\end{array}$ & $\begin{array}{l}\text { Low } \\
\text { Medium }\end{array}$ & Low & & 1 \\
\hline Low & $\begin{array}{l}\text { Low } \\
\text { Medium }\end{array}$ & $\begin{array}{l}\text { Low } \\
\text { Medium }\end{array}$ & Low & & 1 \\
\hline Low & Low & $\begin{array}{l}\text { Low } \\
\text { Medium }\end{array}$ & $\begin{array}{l}\text { Low } \\
\text { Medium }\end{array}$ & & 1 \\
\hline Low & $\begin{array}{l}\text { Low } \\
\text { Medium }\end{array}$ & $\begin{array}{l}\text { Low } \\
\text { Medium }\end{array}$ & $\begin{array}{l}\text { Low } \\
\text { Medium }\end{array}$ & & 1 \\
\hline $\begin{array}{l}\text { Low } \\
\text { Medium }\end{array}$ & $\begin{array}{l}\text { Low } \\
\text { Medium }\end{array}$ & $\begin{array}{l}\text { Low } \\
\text { Medium }\end{array}$ & $\begin{array}{l}\text { Low } \\
\text { Medium }\end{array}$ & & 1 \\
\hline
\end{tabular}


Таблиця А.1 (продовження). Матриця знань для оцінки складової «Організаційна структура»

\begin{tabular}{|c|c|c|c|c|c|}
\hline Medium & Medium & Medium & $\begin{array}{l}\text { Low } \\
\text { Medium }\end{array}$ & \multirow{11}{*}{ Medium } & 1 \\
\hline Medium & Medium & $\begin{array}{l}\text { Low } \\
\text { Medium }\end{array}$ & Medium & & 1 \\
\hline Medium & $\begin{array}{l}\text { Low } \\
\text { Medium }\end{array}$ & Medium & Medium & & 1 \\
\hline $\begin{array}{l}\text { Low } \\
\text { Medium }\end{array}$ & Medium & Medium & Medium & & 1 \\
\hline $\begin{array}{l}\text { Low } \\
\text { Medium }\end{array}$ & $\begin{array}{l}\text { Low } \\
\text { Medium }\end{array}$ & Medium & Medium & & 1 \\
\hline Medium & $\begin{array}{l}\text { Low } \\
\text { Medium }\end{array}$ & $\begin{array}{l}\text { Low } \\
\text { Medium }\end{array}$ & Medium & & 1 \\
\hline Medium & Medium & $\begin{array}{l}\text { Low } \\
\text { Medium }\end{array}$ & $\begin{array}{l}\text { Low } \\
\text { Medium }\end{array}$ & & 1 \\
\hline Medium & $\begin{array}{l}\text { Low } \\
\text { Medium }\end{array}$ & Medium & $\begin{array}{l}\text { Low } \\
\text { Medium }\end{array}$ & & 1 \\
\hline $\begin{array}{l}\text { Low } \\
\text { Medium }\end{array}$ & Medium & $\begin{array}{l}\text { Low } \\
\text { Medium }\end{array}$ & Medium & & 1 \\
\hline High & Medium & Medium & Medium & & 1 \\
\hline High & High & Medium & Medium & & 1 \\
\hline Medium & Medium & Medium & $\begin{array}{l}\text { High } \\
\text { Medium }\end{array}$ & \multirow{9}{*}{$\begin{array}{l}\text { High } \\
\text { Medium }\end{array}$} & 1 \\
\hline Medium & Medium & $\begin{array}{l}\text { High } \\
\text { Medium }\end{array}$ & Medium & & 1 \\
\hline Medium & $\begin{array}{l}\text { High } \\
\text { Medium }\end{array}$ & Medium & Medium & & 1 \\
\hline $\begin{array}{l}\text { High } \\
\text { Medium }\end{array}$ & Medium & Medium & Medium & & 1 \\
\hline $\begin{array}{l}\text { High } \\
\text { Medium }\end{array}$ & $\begin{array}{l}\text { High } \\
\text { Medium }\end{array}$ & Medium & Medium & & 1 \\
\hline Medium & $\begin{array}{l}\text { High } \\
\text { Medium }\end{array}$ & $\begin{array}{l}\text { High } \\
\text { Medium }\end{array}$ & Medium & & 1 \\
\hline Medium & Medium & $\begin{array}{l}\text { High } \\
\text { Medium }\end{array}$ & $\begin{array}{l}\text { High } \\
\text { Medium }\end{array}$ & & 1 \\
\hline Medium & $\begin{array}{l}\text { High } \\
\text { Medium }\end{array}$ & Medium & $\begin{array}{l}\text { High } \\
\text { Medium }\end{array}$ & & 1 \\
\hline $\begin{array}{l}\text { High } \\
\text { Medium }\end{array}$ & Medium & $\begin{array}{l}\text { High } \\
\text { Medium }\end{array}$ & Medium & & 1 \\
\hline High & High & High & High & \multirow{5}{*}{ High } & 1 \\
\hline High & High & High & $\begin{array}{l}\text { High } \\
\text { Medium }\end{array}$ & & 1 \\
\hline High & High & $\begin{array}{l}\text { High } \\
\text { Medium }\end{array}$ & High & & 1 \\
\hline High & $\begin{array}{l}\text { High } \\
\text { Medium }\end{array}$ & High & High & & 1 \\
\hline $\begin{array}{l}\text { High } \\
\text { Medium }\end{array}$ & High & High & High & & 1 \\
\hline
\end{tabular}

